\title{
Response of Growth and Production of Red Ginger (Zingiber Officinale Rubrum Rosc.) to the Use of Compost as a Planting Media
}

\author{
Octanina Sari Sijabat ${ }^{1}$, Triara Juniarsih ${ }^{2}$, Arnila Sari Sijabat ${ }^{3}$, Razali ${ }^{4}$ \\ ${ }^{1}$ Faculty of Agriculture, Universitas Tjut Nyak Dhien, Indonesia \\ ${ }^{2}$ Faculty of Agriculture, Universitas Tjut Nyak Dhien, Indonesia \\ ${ }^{3}$ Faculty of Agriculture, Universitas Samudera, Indonesia \\ ${ }^{4}$ Faculty of Agriculture, Universitas Tjut Nyak Dhien, Indonesia \\ Corresponding Author: Octanina Sari Sijabat
}

\begin{abstract}
Red ginger is a prima donna medicinal plant during this COVID-19 pandemic, because it can help the body's immunity. For this reason, a cultivation method that can increase production is needed. This study aims to see the effect of using compost on the production of red ginger plants. The study was conducted in April 2021 until it was completed. The results showed that the production of red ginger using oil palm empty fruit bunch compost media was higher than other compost media.
\end{abstract}

Keywords: Production, Red Ginger, COVID-19

\section{INTRODUCTION}

Ginger plant (zingiber officinale rosc.) has long been known and grows well in Indonesia. Ginger is one of the important spices, based on Kementrian Pertanian (2014), one type of ginger that is much needed and has high economic value is red ginger. Red ginger is much needed in the traditional medicine industry. Red ginger is used as a medicinal raw material because it has the highest gingerol content compared to elephant ginger and emprit ginger. Based on the results of the analysis of gingerols in ginger rhizomes, it is known that the average gingerol content of red ginger is $5 \%$, ginger emprit has an average gingerol content of $2.3 \%$ and elephant ginger has an average gingerol content of $4 \%$ (Azizah et al., 2018).

Ginger plant is one of the export commodities in Indonesia whose cultivation activities are still not optimal and cause low plant productivity. Efforts to increase productivity so far have only focused on the use of fertilizers and agricultural land extensification. However, currently these two methods are no longer appropriate because the use of chemicals as an intensification effort can have a negative impact on the environment. And efforts to expand land are difficult because the land is getting narrower and as a result of the conversion of agricultural land.

One of the efforts to increase the availability and productivity of red ginger plants that are environmentally friendly is by utilizing compost as a planting medium. The use of planting media in accordance with the growth needs of red ginger is believed to increase the productivity of ginger plants. The purpose of this study was to determine the effect of compost planting media on the growth and production of red ginger.

\section{MATERIALS AND METHOD}

This research is using experimental method. The experimental method involves the manipulation of variables to establish cause and effect relationships (Pandiangan, 
2015). This research was conducted in the experimental garden of the Faculty of Agriculture, Tjut Nyak Dhien University from April to October 2021.

According Pandiangan et al. (2018), sampling is the selection of samples based on certain characteristics that are considered to have relevance to the characteristics. Soil sample analysis was carried out at Center for the Assessment and Development of Agricultural Technology (BP2TP) Medan.

Library research of reference sources is a form of research that uses library facilities by examining theoretical discussions from various books, articles, and scientific works related to writing (Pandiangan, 2018). Library research from Center for the Assessment and Development of Agricultural Technology (BP2TP) Medan.

The study used an experimental method designed with a completely randomized design (CRD). CRD is one where the treatments are assigned completely at random so that each experimental unit has the same chance of receiving any one treatment (Pandiangan et al., 2021). Completely randomized design (CRD) consisting of 4 treatments and 5 replications.

The treatments in this research are:

P0: Top soil + chemical fertilizer (control).

P1: Top soil + compost of empty palm oil bunches (1:1).

P2: Top soil + cow dung compost (1:1).

P3: Top soil + chicken manure compost (1:1).

Data analysis used statistical analysis of variance (ANOVA) test. Analysis of variances (ANOVA) is a statistical examination of the differences between all of the variables used in an experiment (Tobing et al., 2018). This analysis is intended to test whether there is an effect of treatment on each response variable due to differences in the treatment being tried. If the results of data analysis show a real or very significant effect of each treatment on each response variable, then the average difference test is carried out using the BNJ test statistic 0.05. Parameters observed in this study were plant height and number of rhizome production from each treatment.

\section{RESULTS AND DISCUSSION}

Plant Height (Centimeter)

Plant Height Observation Table 19MST

\begin{tabular}{|c|c|c|c|c|c|c|c|}
\hline \multirow[t]{2}{*}{ Treatment } & \multicolumn{5}{|c|}{ Replication } & & \\
\hline & $\mathbf{I}$ & II & III & IV & $\mathbf{V}$ & & \\
\hline $\mathrm{P} 0$ & 44.29 & 43.72 & 45.28 & 56.98 & 60.30 & 250.57 & 50.11 \\
\hline $\mathrm{P} 1$ & 48.06 & 60.46 & 58.02 & 56.93 & 62.00 & 285.47 & 57.09 \\
\hline $\mathrm{P} 2$ & 48.34 & 55.29 & 56.93 & 55.42 & 54.02 & 270.00 & 54.00 \\
\hline P3 & 50.77 & 51.01 & 46.89 & 50.03 & 47.92 & 246.62 & 49.32 \\
\hline Total & 191.46 & 210.48 & 207.12 & 219.36 & 224.24 & 1052.66 & 52.63 \\
\hline
\end{tabular}

\begin{tabular}{|c|c|c|c|c|c|c|c|}
\hline SK & DB & JK & KT & \multicolumn{2}{|c|}{ Fcount } & \multicolumn{2}{|c|}{ Ftable } \\
\cline { 6 - 8 } & & & & & $\mathbf{0 . 0 5}$ & $\mathbf{0 . 0 1}$ \\
\hline Treatment & 3 & 195.32 & 65.11 & 2.45 & tn & 3.24 & 5.29 \\
\hline Error & 16 & 424.59 & 26.54 & & & & \\
\hline Total & 19 & 619.91 & & & & & \\
\hline
\end{tabular}

Based on the results of the ANOVA test, the effect of using several types of compost as a planting medium on the height of red ginger plants. The obtained results are not real because the calculated $F$ value obtained is smaller than the $\mathrm{F}$ table at the $5 \%$ significance level. So the difference between the mean treatment values did not have a significant difference.
Although ginger is grown in the same area, if the environment where it grows is different, it will affect the growth and development of the plant which is expressed through the appearance of its phenotype. Based on Irawan and Purbayanti (2008), which stated that although a cultivar comes from the same area, if the environment where it grows is different it 
will affect genetic diversity and also genotypes originating from the same area are not always in the same group.

On plant height parameters for red ginger 50.11-57.09 $\mathrm{cm}$ at $19 \mathrm{mst}$. Characteristic Common in ginger stems are stems covered by leaf sheaths, wet and dry contains a lot of water, the part of the stem contained in the soil is fleshy, has forked. This is in accordance with the literature which states that ginger is a stem pseudo consisting of fused leaf midribs (Rostiana et al., 1991). Usually the stem is decorated with colored dots white.

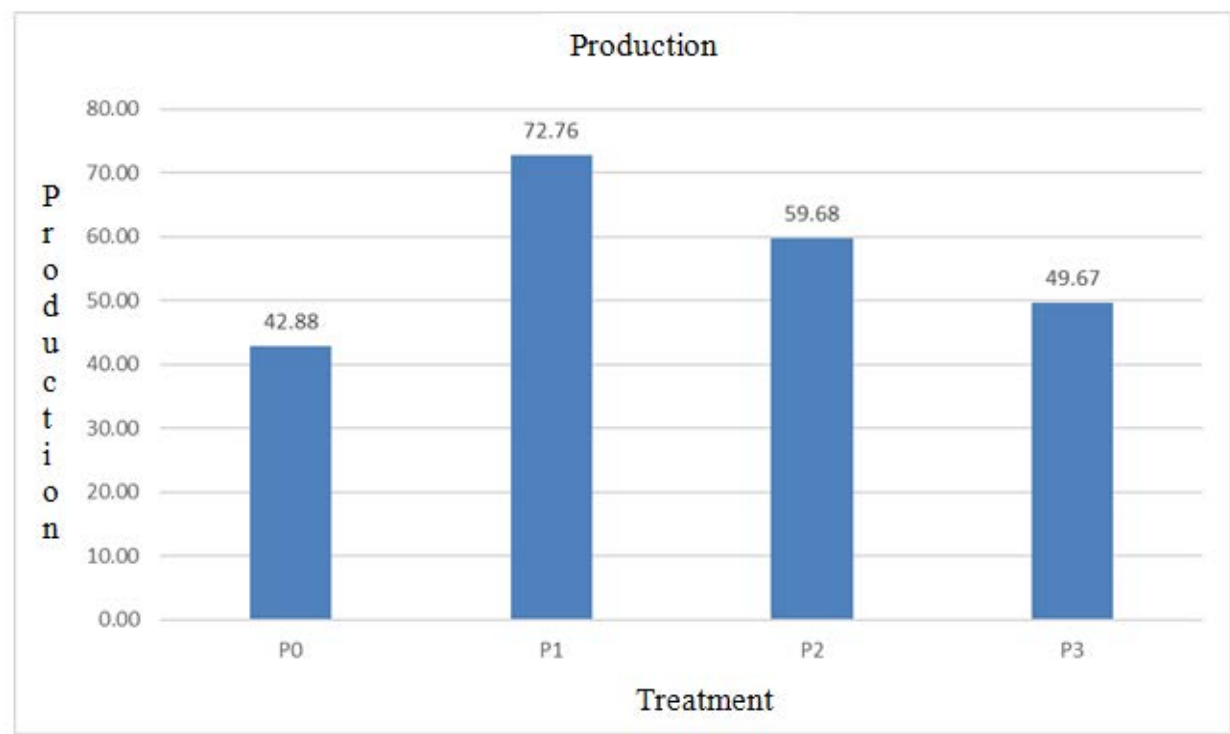

Figure 1: Red Ginger Plant Production Chart (Grams)

The graphic of red ginger rhizome production showed that treatment 1 (P1) had the highest production rate among other treatments. The difference in the production of P1 to P0 is very significant because it has a difference in rhizome weight of 29.88 grams. In addition, the $\mathrm{P} 1$ treatment also had ANOVA test results which showed significantly different results. The test results are in the following table.

\begin{tabular}{|c|c|c|c|c|c|c|c|}
\hline SK & DB & JK & KT & \multicolumn{2}{|c|}{ Fcount } & \multicolumn{2}{|c|}{ Ftable } \\
\cline { 6 - 8 } & & & & & $\mathbf{0 . 0 5}$ & $\mathbf{0 . 0 1}$ \\
\hline Treatmen & 3 & 2531.45 & 843.82 & 15.15 & $* *$ & 3.24 & 5.29 \\
\hline Error & 16 & 891.44 & 55.71 & & & & \\
\hline Total & 19 & 3422.89 & & & & & \\
\hline
\end{tabular}

Based on the results of the ANOVA test, the effect of using several types of compost as a planting medium on the production of red ginger plants. Real results were obtained because the calculated $\mathrm{F}$ value obtained was greater than $\mathrm{F}$ table at $5 \%$ and $1 \%$ significance levels. So the difference between the mean treatment values has a very significant difference.

From the picture it can be seen that the highest production of ginger is produced using tankos compost planting media because of the good macro and micro nutrient content, this is in accordance with research Hayat and Andayani (2014) which states that oil palm tankos compost is used for rice cultivation. can increase soil $\mathrm{pH}$ for the better, and have a significant effect on the amount of chlorophyll so it is good for plants. Compost also increases the availability of macro and micro nutrients that can support plant growth, increasing the capacity of the soil to hold water. Because to get optimal plant growth, it requires fertilizer with the right dose and method of administration. The results showed that the higher the organic fertilizer applied, the better the growth of ginger plants. 

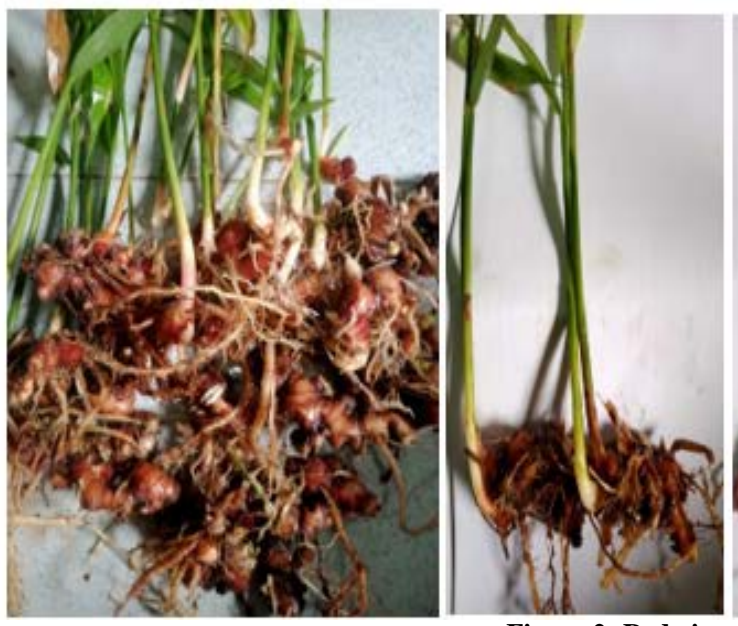

Figure 2: Red ginger plants
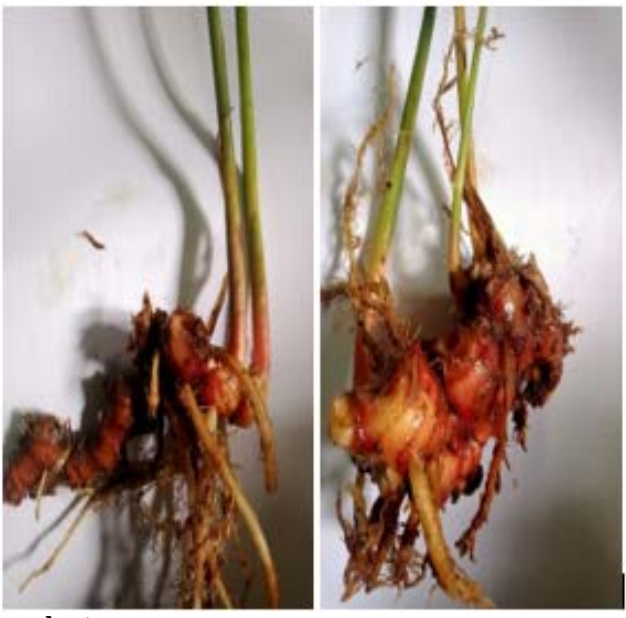

Kerja Terdidik di Kota Medan. Skripsi. Medan: Fakultas Ekonomi dan Bisnis, Program Studi Ekonomi Pembangunan, Universitas Sumatera Utara. https://www.academia.edu/52494724/Analis is_Lama_Mencari_Kerja_Bagi_Tenaga_Ker ja_Terdidik_di_Kota_Medan.

6. Pandiangan, Saut Maruli Tua. (2018). Analisis Faktor-faktor yang Mempengaruhi Penawaran Tenaga Kerja Lanjut Usia di Kota Medan. Tesis. Medan: Fakultas Ekonomi dan Bisnis, Program Studi Ilmu Ekonomi, Universitas Sumatera Utara. http://repositori.usu.ac.id/bitstream/handle/1 23456789/10033/167018013.pdf?sequence= 1\&isAllowed $=\mathrm{y}$.

7. Pandiangan, Saut Maruli Tua, Rujiman, Rahmanta, Tanjung, Indra I., Darus, Muhammad Dhio, \& Ismawan, Agus. (2018). An Analysis on the Factors which Influence Offering the Elderly as Workers in Medan. IOSR Journal of Humanities and Social Science (IOSR-JHSS), 23(10), 76-79. DOI: 10.9790/0837-2310087679.

8. Pandiangan, Saut Maruli Tua, Resmawa, Ira Ningrum, Simanjuntak, Owen De Pinto, Sitompul, Pretty Naomi, \& Jefri, Riny. (2021). Effect of E-Satisfaction on Repurchase Intention in Shopee User Students. Budapest International Research and Critics Institute-Journal, 4(4), 77857791.

DOI: https://doi.org/10.33258/birci.v4i4.2697.

9. Rostiana, O., A. Abdullah., Taryon, \& E. A. Hadad. (1991). Jenis-jenis Tanaman Jahe. Edisi Khusus Penelitian Tanaman Rempah dan Obat, 7(1):7-10.

10. Tobing, Murniati, Afifuddin, Sya'ad, Rahmanta, Huber, Sandra Rouli, 
Octanina Sari Sijabat et.al. Response of growth and production of red ginger (Zingiber Officinale Rubrum Rosc.) to the use of compost as a planting media.

Pandiangan, Saut Maruli Tua, \& Muda, Iskandar. (2018). An Analysis on the Factors Which Influence the Earnings of Micro and Small Business: Case at Blacksmith Metal Industry. Academic Journal of Economic Studies, 5(1), 17-23. https://www.ceeol.com/search/articledetail?id=754945.
How to cite this article: Octanina Sari Sijabat, Triara Juniarsih, Arnila Sari Sijabat et.al. Response of growth and production of red ginger (zingiber officinale rubrum rosc.) to the use of compost as a planting media. International Journal of Research and Review. 2021; 8(12): 468-472. DOI: https://doi.org/10. 52403/ijrr.20211258 